\title{
Talking of harmony
}

\section{Washington}

1989 ends with patent lawyers hopeful that at long last the holy grail of patenting the international harmonization of patent laws - lies within their sight, if not yet within their grasp. The reason for this surge of optimism is the unexpected success of the World Intellectual Property Organization (WIPO) set up last year in Geneva under UN sponsorship.

Unlike two earlier organizations that attempted harmonization of patent law, WIPO involves 121 countries, not just the patent offices of Europe, the United States and Japan. WIPO sponsored a successful meeting in Geneva in November at which patent experts examined the details of a draft harmonization treaty. It will sponsor a second meeting next June, with the aim of preparing a treaty for a diplomatic conference in June 1991.

The draft treaty that WIPO discussed in November would bring in some striking changes. The most contentious for the United States is a change from a 'first-toinvent' system to the 'first-to-file' system practised in Japan and Europe in which the patent is granted to whoever wins the race to the patent office. Although proponents of the US system contend that it is fairer, the procedures to determine who was first to invent are time-consuming and expensive.

Many of the clauses in the treaty are hotly disputed by all WIPO members, but one that meets with few obstacles is the plan for a uniform 'grace period' - the time before a patent application is filed during which the disclosure of a competing invention cannot influence the granting of a patent. The United States allows a grace period of one year and Japan six months but Europe has no grace period at all. This difference is one of the most troublesome for those filing for patents in several different countries. Most members agree on a 12-month grace period.

A rule that patent applications must be published no later than 18 months after they are filed is strongly supported, with objections only from the United States and New Zealand. The United States complains that it is unfair to publish a patent application because if the patent is not subsequently granted, valuable secrets may be given away. As the US patent office grants patents, on average, about 18 months after the date of application, the United States argues that there is no need for compulsory early publication, especially as much of the information is disseminated in scientific jurnals. But Japan argues that early publication benefits both everybody because it avoids a long period of insecurity during which the contents of patent applications remain unknown.

Japan's preference for early publication is in part explained by the remarkable length of time it takes to examine patents. Not surprisingly, Japan objects to attempts to put a time limit of 18 months on examination of patents. Opposing the United States, United Kingdom, the Soviet Union and others supporting the limit, Japan argues that strict time limits have no place in an international treaty because many unpredictable factors, such as surges in the number of patent applications or a shortage of patent officers, could block even efforts made in good faith to meet them

One article in the draft treaty which could reduce the enormous number of patents currently clogging up the Japanese system gains universal support. The article broadens the meaning of "unity of invention', so that technically related features of an invention are all protected under one patent, rather than under several different ones as is now common.

The question of patent lifetime provokes much argument. The draft WIPO treaty would provide 20 years protection. Uruguay is among those that argue that 20 years is too long, and India argues that the term should vary for different fields of

\section{Court battle ends at the start}

\section{Washington}

ONE of biotechnology's longest-running battles was expected to end last week but now looks set to go into a new round of bargaining and bickering. On Monday 11 December a Boston court ruled that neither of the two protagonists - Genetics Institute of Boston and Amgen Corporation of Thousand Oaks, California - has a clear overall right to produce recombinant erythropoietin (EPO) by genetic engineering. In the short term, the ruling seems to favour Genetics Institute. EPO is a kidney cell protein that stimulates bone marrow red-blood-cell production, and annual worldwide sales are expected to reach between $\$ 250$ million and $\$ 1,000$ million.

The ruling, which is complex and runs to 184 pages, validates the central claims of the patents held by the two companies but at the same time doubles the confusion by considering both patents partially invalid and mutally infringing.

The Genetics Institute patent, issued in June 1987 after the company purified EPO from human urine, refers to "homogeneous human EPO", a term that the company claims to include recombinant EPO. The Amgen patent, issued in October 1987, covers the gene, vectors and cells required for production of recombinant EPO, although the patent did not specify the product itself.

Genetics Institute's version of recombinant EPO is called Marogen and is currently only in experimental use in the United States as it has not gained Food and Drug Administration (FDA) approval.

Amgen's recombinant EPO, called Epogen, gained FDA approval in June, 1989 and already has sales of more than $\$ 50$ million.

The most immediate effect of the court decison may be to make it easier for Genetics Institute to produce Marogen abroad. The Amgen patent has so far prevented Genetics Institute from manufacturing recombinant EPO in the United
States. But it has been getting around the restriction by licensing Marogen to Chugai Pharmaceuticals of Japan and importing the product into the United States.

The new ruling found that offshore production of recombinant EPO by Chugai Pharmaceuticals does not infringe the Amgen patent, effectively putting an end to legal action by Amgen designed to prevent the import of Marogen. Even worse for Amgen, the ruling says that Amgen cannot produce Epogen in the United States without infringing the Genetics Institute patent. That puts Amgen in the same boat as Genetics Institute, which cannot produce recombinant EPO without infringing Amgen's patent. Amgen says that the ruling is unlikely to affect the availability of Epogen to patients. The stage looks set for a tussle over some form of crosslicensing agreement.

But Amgen may try to gain an advantage by waiting for the outcome of actions associated with a wider EPO dispute. Amgen has submitted two EPO process patents. If they are granted, Chugai Pharmaceuticals would be prevented from importing recombinant EPO into the United States.

Amgen is also benefiting from 'orphan drug' status for Epogen, granted by FDA for the treatment of anaemia in patients with chronic renal failure. This provides Amgen with a seven-year monopoly in the United States (see Nature 339, 493; 1989). Marogen, which is awaiting FDA approval for sale in the United States, could receive equivalent status if the FDA declares it to be a product distinct from Epogen. If not, an agreement may be negotiated whereby the orphan-drug status of Epogen is shared with Genetics Institute in return for Amgen not paying royalties in a cross-licensing agreement.

Both parties may, however, wish to see a speedy resolution to the dispute as the market for EPO is huge. Dlane Gershon NATURE · VOL $342 \cdot 21 / 28$ DECEMBER 1989 
technology. The decision on patent lifetime will not rest with WIPO, however, but with GATT (General Agreement on Tariffs and Trade), which will be considering harmonizing the term of patent protection in discussions of intellectual property rights next year.

Developing nations will be anxious for terms that recognize their special circumstances - the need to have access to sophisticated drugs at reasonable prices, for example. They intend to meet in Geneva before the June WIPO meeting in order to thrash out a common position on the treaty.

Christine McGourty

\section{AIDS \\ East Berlin risks grows}

\section{Munich}

TANGERINES and tape recorders are not all that East Germans are bringing back from their trips to West Berlin. Unless East German citizens take precautions, AIDS may be the next big import from the capitalist West. That is the view that emerged when East German public health official Niels Sönnichsen visited an AIDS self-help group in West Berlin.

Sönnichsen, who is at the East German Ministry of Health, and his counterparts in West Berlin have begun an information and condom distribution campaign. The campaign is unprecedented in East Germany, where AIDS was a taboo subject until just a few weeks ago. It is aimed at homosexual men, the only group currently at high risk for AIDS in East Germany. The main message: practise safe sex while in West Berlin.

With 16 confirmed cases of AIDS and seven deaths, East Germany has always been one of the most AIDS-free countries in Europe. By contrast, West Berlin, a city of about 2 million, has had 882 AIDS cases and 349 deaths, according to the West German Federal Health Office. The number of AIDS virus carriers in West Berlin is estimated to be between 5,000 and 10,000 . East Germany, with a population of more than $\mathbf{1 6}$ million, is thought to have 200 to 400 carriers.

But many of the West Berliners infected have been intravenous drug users, as many as $\mathbf{4 0}$ per cent of whom are thought to carry the virus. As there is virtually no drug trade in East Germany, only homosexuals are thought to be at risk there.

A self-help group, Berliner AIDS-Hilfe, has distributed condoms at homosexual meeting places in West Berlin since the wall was opened. The next step, said spokeswoman Birgit Thomas-Schön, is to give doctors in East Berlin training in diagnosis and counselling. But AIDS cannot be stopped at the border, says Meinrad Koch, head of the AIDS centre of the Federal Health Office in West Berlin.

Steven Dickman

\section{Rescue mission prepared}

\section{Washington}

THE mission of space shuttle Columbia, scheduled tentatively for launch on 8 January 1990 , will be the first occasion on which the shuttle performs a task that was originally intended to have been one of its routine activities - the return to Earth of a satellite put into orbit on a previous shuttle flight. If all goes well, the crew of Columbia will manoeuvre the shuttle next to a cylindrical canister known as the Long Duration Exposure Facility (LDEF), pull it into the cargo bay, and bring it back down to Earth, where scientists will see the outcome of 66 experiments that have been sitting in the cold and the dark for five and a half years.

LDEF, put into orbit in April 1984, is a 12 -sided cylinder, 30 feet long and 14 feet in diameter, holding 86 trays that contain a variety of simple experiments in physics, astronomy and biology. It was supposed to stay in low orbit for about a year, but before it could be retrieved, the Challenger explosion of January 1986 grounded the shuttle fleet for three years. This week's [planned] flight is an eleventh-hour mission: Columbia is the only shuttle with a cargo bay big enough to hold LDEF, and if the retrieval attempt fails, LDEF, now in a rapidly decaying orbit, will burn up in the Earth's atmosphere, probably by February next year.

The unexpected length of LDEF's flight, and the consequently aggravated effects of the upper atmosphere on its contents, could turn out to be the biggest problem for some of the experiments on board, according to Ernst Zinner, of Washington University in St Louis, Missouri, who is principal investigator of an experiment to capture interplanetary dust. Zinner's payload on LDEF consists of a number of 'sandwiches' of germanium plates in metallicized plastic foil coatings. Dust particles, travelling at speeds of 10 $\mathrm{km}$ per second, penetrate the foil but crash into the germanium and vaporize; the lower-speed fragments should then be retained by the foil coatings, so that the sandwiches retrieved from LDEF should harbour a five-year accumulation of deposited atoms whose isotopic composition will offer clues as to the origin of the dust. But Zinner is worried that some of his germanium sandwiches, placed in trays at the leading edge of the LDEF, will have been poisoned or damaged by the long exposure to atmospheric oxygen, in which case the germanium will contain an inseparable mix of terrestrial and extraterrestrial atoms.

But the unexpectedly long exposure of LDEF to the elements of space should also bring some rewards. Many of the experiments on board were designed to assess the damage suffered by a variety of materials on long exposure to dust, cosmic rays and meteorites, and the body of the LDEF canister itself will be examined closely for pitting and other ill-effects. This whole investigation will add greatly to the sparse body of knowledge on the durability of man-made structures in space, and should provide food for thought for the engineers now designing the space station.

One final LDEF experiment will give schoolchildren across the United States the chance to participate in a little space research. The George W. Park Seed Company of Greenwood, South Carolina, provided 12.5 million tomato seeds in packages loaded on to the LDEF for the Space Exposed Experiments Developed for Students (SEEDS), and set aside another 12.5 million which have been maintained in a sealed environment on the ground since April 1984. The tomato seeds will be divided up into kits of 50 exposed and 50 control seeds, and will be distributed to 250,000 schools as well as to some universities. Students are then free to investigate the effects of space exposure how they choose; young schoolchildren will be able to compare germination rates and times, while university students can look for genetic changes.

David Lindley

RESEARCH COUNCILS

\section{NERC on the up}

\section{London}

A "RESURGENCE" in the fortunes of the UK Natural Environment Research Council (NERC) after years of financial attrition, is the optimistic message of the council's report for the year ending 31 March 1989. At a press conference to publicize the report, NERC chairman Professor John Knill described how a 20 per cent rise in government funding over that for 1987-88 reflected "a dramatic change in public and political attitudes to environmental issues".

But the increase in resources available to NERC since the science budget announced in November 1988 did not prevent a 7 per cent cut in staff numbers over the year, a hangover from earlier financial problems. This year's science budget has yet to be allocated among the research councils.

The report also comments on proposals to reorganize the administration and funding of UK environmental research. NERC is opposed to a full merger with the Agriculture and Food Research Council (AFRC), first suggested by the House of Lords select committee on science and technology in October 1988. Nevertheless, there is "considerable logic in a partial merger between AFRC and NERC", perhaps within a division of a single National Research Council. Peter Aldhous 